\title{
Dentification and Charateristics of Genetic Resources of Orange Plants I District Bangli-Bali
}

\author{
Nengah Suaria $^{*}$, Ni Putu Anom Sulistiawati ${ }^{2}$, Ni Komang Alit Astiari ${ }^{3}$ \\ Universitas Warmadewa, Denpasar, Bali-Indonesia \\ \{n.suaria@gmail.com¹, anomsulistia@gmail.com²
}

\begin{abstract}
Morphological Characteristics of Some Citrus Plants in Bangli Regency. Citrus fruit plants are a small part of the types of fruit cultivated, starting from June to October 2020. The research aimed to find out information on the morphological characteristics of citrus plants found in Bangli Regency. The research was conducted using descriptive methods. Data collection and processing was carried out by describing morphological characteristics such as: the shape of the stems, fruit, flowers and leaves of citrus plants. The results of this study obtained 24 types of citrus plants in Bangli. The kinship analysis of the 24 types of oranges that were sampled based on 30 characteristics means that there is a very close relationship between the Siamese citrus species and the tangerines, based on the shape of the fruit, namely the coefficient or similarity of $93 \%$, a very far relationship is found in small fruit lime, namely the coefficient $50 \%$
\end{abstract}

Keywords: Genetic Power; Identification; Orange; Morphology

\section{Introduction}

Bali is rich in horticultural resources, especially fruits, but this wealth has not been optimally utilized. Fruits in Bali are not only used for consumption by local residents, but also for hotel needs related to Bali as a tourist destination, and to fulfill the religious ritual needs of the Balinese Hindu community. Utilization of fruits such as oranges must be done wisely to ensure a sustainable supply while maintaining and improving the quality of tropical fruits. The genetic resources of tropical fruits are very abundant and have different characteristics from those in other regions. The genetic resources of local fruits, such as oranges, are all types and varieties of fruits that have been developed and cultivated in a certain area so that they become a typical fruit in that area. Local citrus fruits are one of the genetic resources that have great potential that have not been cultivated in the context of realizing the integration of agriculture and tourism [1]. Regional Regulation No. 3 of 2013 needs to be realized so that germplasm as a source of local Balinese fruits is protected and its development can be carried out as well as possible. Development actions taken are actually an obligation to maintain the balance and welfare of nature, because nature is a place and source of life for human life. Therefore, all types of genetic resources that are owned must be preserved from generation to generation. One of the important things stated in the Perda on Local Fruit Protection is the need for the Bali Provincial Government to empower and protect genetic resources and local fruit products through integration with tourism. Local fruit plants, especially citrus fruit on the island of Bali, are scattered in Bangli district in Bali. Bangli Regency is a district that produces local fruits, 
especially citrus fruits, which have not been well explored and recorded. This research will identify local hoticultural fruits, especially citrus fruits. Horticultural fruit is a plant product that comes from the continuous development of pollen and pistil fusion which is consumed fresh and cannot be stored for a long time [2]. The identification and characterization of local fruit, especially citrus fruit in Bangli Regency, was carried out by exploration. Exploration is field exploration with the aim of gaining more knowledge about the situation, especially the natural resources found in that place. The collected data is expected to be the initial data base for the protection of the genetic resources of citrus fruit plants in Bali, especially in Bangli Regency. After the collection of local citrus fruit data in the field, a geographic mapping of genetic resources was carried out as a basis for the protection, preservation and development of citrus fruit trees in Bangli Regency. The objectives of this study were: 1) to identify morphological characteristics of plants including canopy, stems, leaves, flowers and fruits; 2) identify the characteristics of each type of citrus fruit plant, so that it becomes an attraction and can become a characteristic that differentiates the types of citrus fruit varieties from one another

This study aims to identify and explore the character of the citrus fruit species owned by each of the three sub-districts in Bangli Regency. This research, it is hoped that the distribution of areas that cultivate cultivated citrus types can be identified and the types of citrus cultivated from the three sub-districts in Bangli Regency. so that it is smoother and more efficient in order to increase the distribution of citrus fruit agribusiness

\section{Method}

The research was conducted for six months, from June to December 2020. This research was carried out in Bangli Regency which consists of four districts, namely: Bangli District, Susut District, Kintamani District, and Tembuku District.

\subsection{Materials and Tools}

The materials and tools used include cameras, altimeters, GPS (Global posittion system), rulers, razors, loops (magnifying glass), knives, meters, label paper, plastics, stationery, books for identification and characterization entitled Flora [3].

\subsection{Research implementation}

Implementation of the research consists of three stages of activity, namely, (1) secondary data collection, (2) primary data collection, (3) identification of morphological and agronomic characters from genetic resources, identification of the growing environment and knowing the benefits of fruit from each citrus fruit that has been identified.

\subsection{Secondary Data Collection}

Secondary data collection aims to obtain initial information about the genetic resources of citrus fruit plants and their distribution in Bangli Regency. Secondary data were collected from various agencies and sources such as: statistical data, annual reports, literature and publications that reveal the genetic resources of citrus fruit plants in Bangli Regency. 


\subsection{Primary Data Collection}

- Direct observation. Collecting data by visual means. Based on the data and information obtained from the secondary data above, a survey (field observation) was carried out to find the types of genetic resources of citrus fruit in Bangli Regency which include the location found (village, subdistrict), growing environment (yard, moor), rice fields, plantations, forests).

- Interview Interviews were conducted by direct question and answer with farmers or owners of citrus fruit trees found in the field.

\section{Result And Discussion}

\subsection{Overview of the Research Area}

Bangli Regency is a regency in Bali which has no coastal area. The geographical location of Bangli Regency is between 115o 13 '48 "to 115o 27' 24" East Longitude and 8o 8 '30 "to 80 31' 87" South Latitude, with an altitude of $100-2,152 \mathrm{~m}$ asl and rainfall ranging from $400 \mathrm{~mm}$ per year [4]. Bangli Regency has administrative boundaries as follows: Buleleng Regency (North), Karangasem Regency (East), Klungkung Regency (South), Gianyar Regency and Mundu Regency (West). The area of Bangli Regency is $52,081 \mathrm{Ha}$ or $9.25 \%$ of the total area of Bali Province (563,666 Ha). Administratively, Bangli Regency is divided into 4 subdistricts and 72 villages / wards, namely: Susut, Bangli, Tembuku and Kintamani Districts. The natural conditions that are owned are quite favorable for the development of horticultural crops and agro-tourism.

Identification and characteristics of citrus fruits in Bangli Regency Genetic resources of citrus fruit types found based on sweeping in various places, which are spread across four districts in Bangli Regency, the types of citrus fruit consist of: Tangerine 55 stone (Citrus reticulata Blanco), Sweet orange brastagi (Citrus reticulata), Sweet Orange Valensia (Citrus reticulata), Orange Slayer (Citrus reticulata), red and white grapefruit (Citrus maxima (Burm.) Merr), Sweet orange varigata (Citrus reticulata), besakih tangerines (Citrus reticulata). Brastagi Orange, Valence Orange, Dekopon Orange Leading commodities are commodities that are cultivated based on competitive and comparative advantages supported by the use of technology in accordance with the agroecosystem to increase added value and have a "multiplier effect" on the development of other sectors [5]. LQ (Location quotient) is a method to determine the ability of Bangli Regency in the agricultural sector. The LQ value of Bangli Regency is obtained by comparing the average amount of fruit production in the last five years in Bangli Regency with the average production amount of the province of Bali in the last five years for citrus commodities. The District LQ value is obtained by comparing the average of the District's total production of citrus fruit with the Regency's average production for citrus. The data source used from BPS is Bangli in the 2009-2013 figures and Bali in the 2009-2013 figures, after going through the analysis stage the data is obtained as in Table 1.In Table 1 shows, Bangli Regency has two superior citrus fruits, namely Siamese oranges. , and tangerines, this is indicated by the LQ value of each citrus fruit is more than 1 , which is $1.85 \mathrm{~V}$.

Identification and characteristics of citrus fruits in Bangli Regency genetic resources of citrus fruit types found based on sweeping in various places, which are spread across four districts in Bangli Regency, the types of citrus fruit consist of: Tangerine 55 stone (Citrus reticulata Blanco), Sweet orange brastagi (Citrus reticulata), Sweet Orange Valensia (Citrus 
reticulata), Orange Slayer (Citrus reticulata), red and white grapefruit (Citrus maxima (Burm.) Merr), Sweet orange varigata (Citrus reticulata), besakih tangerines (Citrus reticulata). Brastagi Orange, Valence Orange, Dekopon Orange

\subsection{Types of Leading Citrus Fruit Commodities}

Leading commodities are commodities that are cultivated based on competitive and comparative advantages supported by the use of technology in accordance with the agroecosystem to increase added value and have a "multiplier effect" on the development of other sectors [5]. LQ (Location quotient) is a method to determine the ability of Bangli Regency in the agricultural sector. The LQ value of Bangli Regency is obtained by comparing the average amount of fruit production in the last five years in Bangli Regency with the average production amount of the province of Bali in the last five years for citrus commodities. The District LQ value is obtained by comparing the average of the District's total production of citrus fruit with the Regency's average production for citrus. The data source used from BPS is Bangli in the 2009-2013 figures and Bali in the 2009-2013 figures, after going through the analysis stage the data is obtained as in Table 1.In Table 1 shows, Bangli Regency has two superior citrus fruits, namely Siamese oranges. , and tangerines, this is indicated by the LQ value of each citrus fruit is more than 1 , which is 1.85 .

Table 1. Main Fruit Commodities in District and District

\begin{tabular}{ccccccc}
\hline No & $\begin{array}{c}\text { Jenis buah } \\
\text { jeruk }\end{array}$ & $\begin{array}{c}\text { Nilai LQ } \\
\text { Kabupaten } \\
\text { Bangli } \\
\text { terhadap Bali }\end{array}$ & $\begin{array}{c}\text { Kecamaatan } \\
\text { Susut }\end{array}$ & $\begin{array}{c}\text { Nilai LQ Kecamatan } \\
\text { Kecamatan } \\
\text { Kintamani }\end{array}$ & $\begin{array}{c}\text { Kecamatan } \\
\text { Bangli }\end{array}$ & $\begin{array}{c}\text { Kecamatan } \\
\text { Tembuku }\end{array}$ \\
\hline 1 & Jeruk Keprok & $1,82^{*}$ & 0,89 & $1,82^{*}$ & 0,97 & 0,87 \\
2 & JerukSiam & $1,85^{*}$ & 0,83 & $1,83^{*}$ & 0,67 & 0,76 \\
3 & Jeruk limao & 0,21 & 0,34 & 0,45 & 0,56 & 0,15 \\
4 & Jeruk Brastagi & 0,87 & 0,85 & 0,91 & 0,87 & 0,79 \\
\hline
\end{tabular}

From the KQ value shown by the chayote and tangerine jerk, it shows that the LQ value is greater than 1 so that it needs to be developed.

\subsection{The Potential of Agro-tourism Development}

Given the rapid development of the tourism world in Bali in general and Bangli Regency in particular, the need for horticultural food is increasing. In addition, the need for community fruits, tourism and the needs of foreign markets have made great potential to reach the export market. Therefore, the development of horticultural agriculture is very promising because all people cannot be separated from food sources such as fruits which are needed by the body as a source of vitamins. In addition, the rapid development of tourism in Bangli Regency can make fruit commodities have a great opportunity to be developed. This can be seen, among others, by the large number of imported fruits that enter traditional markets and fill the tourism market. Therefore, the genetic resources of these local fruits need to be utilized as much as possible to meet the needs of the fruits. The genetic resources of local fruits in Bangli Regency that have the potential to be developed are oranges and bananas, which until now the existence of citrus and banana plants is quite attractive for cultivation because of high market demand and high economic value. Other fruits which are classified as superior fruits in each subdistrict in Bangli Regency also have the potential to be developed. This is done to maintain these superior fruits, including avocado, durian, guava, mango, pineapple, papaya, rambutan, salak and sapodilla. The use of each fruit in Bangli Regency is very diverse, this is evidenced 
by the fact that the life of the Balinese people cannot be separated from the existence of traditional ceremonies and religious rituals, to support religious ceremonies and ritual activities of Hindus in Bali, mostly utilizing locally produced fruits . These fruits are used, among others, to make offerings or haturan, gebogan or pajegan, ajuman or sodan, offerings of holiness, chess. One of them is the citrus fruit that has become an icon of Kintamani District, Bangli Regency, until now the Siem Kintamani Orange has entered the export market, between islands, the tourism market, and many locations have become places of agro-tourism [6].

The problem in the field is that the low level of knowledge of the local community's human resources causes these natural and cultural resources to be unable to be managed independently, even though if managed according to standards accompanied by adequate promotion it can become a very attractive and salable tour package for tourists. Community business products such as agricultural products, due to inadequate quality and / or limited access, are not absorbed in the tourism market (hotels and restaurants). The selling value of agricultural products is very low, far below the price prevailing in the tourism market. As a result, the economic benefits generated from tourism are not enjoyed by local communities but are more enjoyed by hotel entrepreneurs and other tourism service entrepreneurs.

\subsection{Identification of Diversity Based on Morphological Characteristics.}

Morphological identification was carried out based on observations of 20 samples with 25 observation variables. Meanwhile, anatomical identification was carried out based on 20 leaves from each tree sampled with 6 observation variables. The analysis was continued by using the cluster analysis method. Cluster analysis is used to analyze diversity and classify plants based on morphologically ientified data and parameters. Group analysis or cluster analysis is a data analysis technique that aims to group individuals / objects into several groups that have different characteristics between groups, so that individuals or objects located in one group will have relatively homogeneous characteristics. The data from the observations on citrus plants is diverse, so that the grouping is carried out by grouping / cluster analysis.

The closeness of the relationship between sample numbers on 20 samples of citrus plants based on group analysis. In the grouping, the distance from 0.0 to 0.1 is the euclidic distance which indicates similar characteristics. The euclidic spacing is used because each feature has a proportional scale. The results of cluster analysis in Catur Village show that, on a scale of 0.492 , nine groups were formed with different morphological diversity. At the end of the scale 0.835 all accessions merge into one group represented by TM04 (group I), KA01 (group II) KA03 and (group III) KA9 (Figure 1). Based on the dendogram above, there are three accessions that have different euclidic spacing, so that it can be determined that the three accessions have different main characteristics for the characters.

\section{Conclusion}

Field observations found 3 types of superior citrus cultivated in four sub-districts in Bangli Regency. The profile of citrus plants is composed of 2 pieces. The profile includes morphological characters, production, and photographs of genetic resources of citrus fruits. Based on the LQ value, Bangli Regency has 3 main commodities, namely oranges and tangerines and brestagi siam oranges. Oranges with the highest production of 10,967 tonnes / year are found in Catur Village, Kec. Kintamani. 


\section{References}

[1] I. N. Rai, C. G. A. Semarajaya, and I. W. Wiraatmaja, "Studi Fenofisiologi Pembungaan Salak Gula Pasir sebagai Upaya Mengatasi Kegagalan Fruit-Set," $J$. Hortik., vol. 20, no. 3, pp. 216-222, 2010.

[2] I. G. A. D. Adelianie, "Penyajian Buah Lokal Dalam Operasional Hotel Berbintang Di Kawasan Pariwisata Sanur," Program Studi Kajian Pariwisata, Program Pascasarjana, Universitas Udayana, 2015.

[3] C. G. G. J. Van Steenis, Flora. Jakarta: Pradnya Paramitha, 2003.

[4] Biro Pusat Statistik Bali, "Bali dalam Angka 2013," 2014. .

[5] S. Dalimartha, Atlas Tumbuhan Obat Jilid 3. Jakarta: Puspa Swara, 2003.

[6] H. Sulistyo, "Implementasi QFD Dalam Meningkatkan Daya Saing Pasar Tradisional,” J. Siasat Bisnis, vol. 15, no. 2, pp. 157-169, 2011. 